\title{
The Contribution of Writing in Students’ Argumentative Skills DEVELOPMENT
}

\author{
Lenka Holečková \\ University of Economics Prague, \\ Faculty of Finance and Accounting, Department of Economic Teaching Methodology, \\ Winston Churchill Sq 1938/4, 13067 Prague 3 - Žižkov, Czech Republic \\ e-mail: lenka.holeckova@vse.cz
}

\begin{abstract}
The paper deals with the contribution of capturing students' ideas in writing to the development of their argumentative skills. It focuses on two forms of writing skills practice free writing and argumentative essay - included in the teaching process. The emphasis is placed on the possible change of students' knowledge related to selected economic topic taught via free writing method or argumentative essay method. These two methods are different: while the argumentative essay follows specific requirements, free writing allows students to write more freely without any fixed outline. Both methods are relatively timeconsuming and challenging both for students and the teacher. The paper looks at the possibility of using these writing forms in the teaching of selected economic topics. The main aim of the paper is to show the contribution of these two selected methods while focusing on their possible enhancement of students' knowledge. In this context, an experiment was carried out and its results are presented and discussed at the end of the paper.
\end{abstract}

\section{Keywords}

Students; Argumentative skills; Argumentative essay; Free writing; Teaching.

\section{Introduction}

Nowadays, the emphasis is placed on the ability of students to succeed on the labor market. They can hardly be successful without the ability to formulate their ideas clearly, to give thought-out arguments and to be persuasive. Undoubtedly, their persuasiveness will bring them the advantage in the future process of searching for a job. That is why it is useful to develop their ability to give appropriate arguments in the learning process.

There exist many ways of argumentative abilities practicing. Within the process of teaching, they could be practiced with the help of active teaching methods. However, active teaching methods are relatively time- consuming for the teacher. The application of each method should be well thought-out, precisely prepared, and its usage in a specific session must be carefully premeditated. In case these aspects are not taken into consideration, there is a danger of losing the aim of the lecture and wasting time.

This paper deals with the usage of two selected methods that could be useful for teacher and for forming of students' argumentative abilities. The first method is argumentative essay, the second one free writing. These methods have a different structure. While argumentative essay has its strict parts, free writing allows students to write more freely without a mandatory structure. The paper deals with the possibility of using these writing forms in the teaching of selected economic topics. The emphasis is placed on the possible change of students' knowledge (related to selected economic topic taught via free writing method or 
argumentative essay method). The change of students' knowledge was researched with the help of an experiment.

\section{The Importance of Students' Argumentative Skills Development}

\subsection{Argumentation as a Factor of a Persuasiveness}

The most important factor in the argumentation is a persuasiveness of the speaker [1]. During the process of persuasion, it is possible to use among others pros and cons arguments, examples or generalization. The arguments must be well-thought and they should support presented opinion. The strongest arguments should be given at the beginning and at the end of the speech.

During the teaching process, it is useful to outline these rules to students. They must be also familiarized with the rules regarding the selected method (argumentative essay, free writing) that will be practiced within the teaching process. It is also necessary to tell them that their ideas will be presented to the audience or shared in the class after the application of selected methods [2].

The following text will outline two selected methods application. Consequently, it will deal with their impact on students' knowledge.

\subsection{Argumentative Essay}

The first method, an argumentative essay, consists of a few obligatory aspects that should be helpful for students to work with their thoughts [3]. The students give their arguments in the written form that should help them to organize their ideas better. The most important thing regarding an argumentative essay is that it is crucial to show both sides of a contentious issue [4]. In other words, the topic must be debatable. There are many ways of organizing the argumentative essay. The main points should be Introduction, Pro points + support, Con points + rebuttal, Conclusion. In other words, the first aspect for students is to present their opinion (regarding a question asked by the teacher). The next aspect should be the evidence that promote the presented idea. Writers use different types of support to argue or prove their points - it depends on the topic. Writers can use for example their personal experience, expert opinion, examples, facts, and statistics to support their ideas. The next significant aspect (after expressing the opinion) is connected with possible arguments against the original idea presented together with the explanation why they are not so important for the final problem solution. Last aspect is a suggested solution itself. After realization of the argumentative essay, it is practical to share students' opinions in the whole class.

\subsection{Free Writing}

The method of free writing is also a written form of giving arguments. The students answer the question that is given by the teacher. The students should write their ideas without stopping for a set period of time (usually 3 - 30 minutes) with no consideration of grammar, punctuation, spelling, or even logical progression [5]. The purpose of free writing is to rely on the subconscious to make associations and to keep the pen moving without editing each word or thought. This could be very useful in helping the students to put their ideas down that they might not have previously considered. After finishing, the students' work can be shared in pairs or in the whole class. 


\section{$2 \quad$ Research Objectives}

The research objectives are focused on the verification of a students' knowledge change significance regarding selected economic topic taught with the help of an argumentative essay and free writing method. The change is measured with the comparison of pre-test and posttest and its significance is verified via paired two sample $t$-test.

\section{$3 \quad$ Methodology}

The research paper is dealing with the main research question: "Is there a significant influence of the applied argumentative methods on students' knowledge?" The research was realized at the grammar school in Prague 4 (the name is not specified in the research paper because of the wish of the grammar school management) in the subject of Economics. Economics is a facultative subject for final graders. The aim of this subject is to prepare the students for further university studies.

The change of students' knowledge was researched with the help of an experiment. The students were divided into two groups; in both groups, the same topic was taught. Before dealing with the topic, students wrote a didactic test (pre-test) that found out the entrance knowledge of selected economic topic in the group. Subsequently, the economic topic was taught. In the end of the learning process, a controversial question regarding the topic was asked. The first group answered it with the help of argumentative essay, the second one with the help of free writing. After this writing phase, the knowledge of the topic was evaluated again with the same didactic test - post-test. The influence of both writing forms on students' knowledge was assessed. The importance of differences between pre-test and post-test was evaluated via the method of paired two sample $t$-test.

The primary methods used in the research are didactic experiment and didactic test. The test consisted of 20 multiple-choice questions. Each correct answer was evaluated with 1 point. In some questions, more than 1 answer was correct. The total number of correct answers was 25 and the total test score was 25 points. Time capacity for the test was $20-30$ minutes. For the pairing of the pre-test and post-test, it was necessary for each student to put their signature on the test. The final research sample contained only the students participating both in the pretest and post-test. The method of paired two sample $t$-test was used for the measuring of the change of students' knowledge. Before usage of paired two sample $t$-test, Shapiro-Wilk test for normal distribution was used. The data were processed with the help of MS Excel and Data Analysis in MS Excel.

The research is focused primarily on pre-test and post-test comparison and verification of a significance of related students' knowledge change. Its aim is not to compare both used writing forms regarding their significance.

\section{$4 \quad$ Research}

In the following text, the influence of two selected active teaching methods (argumentative essay and free writing) on students' economic topic knowledge is researched with focus on the possibility to bring a significant change of students' knowledge.

Economics was taught in two parallel groups of 25 students. The research was realized in January 2017 in connection with the topic "Labor market and unemployment". For the verification of students' knowledge, two didactic tests were used. Before teaching itself, pretest related to the topic of "Labor market and unemployment" was given to the students. The main purpose of the pre-test was to assess their general knowledge of the topic before 
covering it in the subject. After the pre-test, the topic was taught. One group dealt with it with the help of the method of free writing, the second group with the help of argumentative essay.

The topic itself was not introduced by classic frontal teaching. The task for students was introduced in the form of the following statement: "Unemployment benefits could demotivate people to be active in searching for an appropriate job". After realization of these tasks, there was a discussion and explanation given by the teacher. One week after the realization of this topic, the same version of post-test was written (in accordance with the recommendations of selected authors [6], [7]). The students were not informed about the test in advance (because of their possible motivation to remember the pre-test questions). For the reason of the pre-test and post-test pairing, it was necessary for the students to participate both on pre-test and posttest (non-paired tests were taken out).

Based on the above mentioned methodology, the research was realized. Firstly, Shapiro-Wilk test for normal distribution was calculated on 23 and 24 data points (the number of students in both groups). Null hypothesis "The data can be modeled according to the normal distribution" was verified. The base of the test is that when the $P$ value is small enough it is possible to conclude that the data set is not following the normal distribution. The threshold value for $P$ was set up on the level of 0.05 . In all cases, $P$ value was higher than 0.05 . It is visible from Table 1.

Tab. 1: Shapiro-Wilk test results

\begin{tabular}{|l|c|c|c|c|}
\hline Method & \multicolumn{2}{|c|}{ Argumentative essay } & \multicolumn{2}{c|}{ Free writing } \\
\hline Pre-test/post-test & Pre-test & Post-test & Pre-test & Post-test \\
\hline Probability $(\boldsymbol{P}$ value $)$ & 0.146 & 0.239 & 0.412 & 0.368 \\
\hline
\end{tabular}

Source: own research, [8]

The results showed normal distribution of analyzed data. It was not necessary to transform them and $t$-test could be realized.

On the basis of applied pair $t$-test it was found that there was a significant change of knowledge regarding both methods (argumentative essay, free writing). It is visible from Table 2 and Table 3. In the Table 2, the results of argumentative essay method are introduced. The results show the significant difference between pre-test and post-test. Threshold value for $\mathrm{P}$ was set up on the level of 0.05 . Probability $P$ was lower than $0.05-$ it means that there is a significant influence of argumentative essay method on students' knowledge.

Tab. 2: Argumentative Essay - t-test results

Source: Own research using $M S$ Excel

\begin{tabular}{|l|l|l|}
\hline Results & Variable 1 & Variable 2 \\
\hline Mean & 10 & 15.5 \\
\hline Variance & 12.347826 & 23.304348 \\
\hline Observations & 24 & 24 \\
\hline Pearson Correlation & 0.66895814 \\
\hline $\boldsymbol{P}(\boldsymbol{T}<\boldsymbol{t})$ two-tail & $1.31582 \mathrm{E}-07$ \\
\hline
\end{tabular}

It is also visible from the table above that the average change of points between pre-test and post-test was 5.5 points. It brings the improvement of students' knowledge by $55 \%$.

Table 3 refers to the results of $t$-test in connection with free writing method. The results show the significant difference between pre-test and post-test, too. $P$ value was lower than 0.05 and it means that there is a significant influence of free writing method on students' knowledge. 
Tab. 3: Free Writing - t-test results

Source: Own research using MS Excel

\begin{tabular}{|l|l|l|}
\hline Results & Variable 1 & Variable 2 \\
\hline Mean & 9.7826087 & 15.869565 \\
\hline Variance & 11.086957 & 20.391304 \\
\hline Observations & 23 & 23 \\
\hline Pearson Correlation & 0.705427527 \\
\hline $\boldsymbol{P}(\boldsymbol{T}<=\boldsymbol{t})$ two-tail & $6.38071 \mathrm{E}-09$ \\
\hline
\end{tabular}

It is also visible from the table above that average change of points between pre-test and posttest was 6.1 points. It brings the improvement of knowledge by $62 \%$.

Now it is possible to answer the research question. The results of $t$-test showed that there is a significant influence of the applied argumentative methods on students' knowledge.

\section{Discussion}

To sum it up, based on the research, more significant change was caused by free writing method that brings more significant score change. The difference between the pre-test and the post-test is 6.1 points (improvement by 62\%) in comparison with the argumentative essay method results (5.5 points and 55\%). It could be supposed that argumentative essay with its clear structure and strict rules could bring higher changes than relatively "free" method of free writing based on students' associations. However, these differences could be caused just by formed associations and following remembering that could be better while writing freely.

However, the students were surprisingly more interested in the argumentative essay. It could be caused by the fact that this method has its clear structure that gave them relatively clear idea what to write. Unlike the method of free writing, they were able to start their writing very quickly and did not hesitate what to write. In the process of free writing, some students seemed to be lost. That is why they were not fully interested in this method. It could be caused by the fact that nowadays they are not used to writing consistent ideas. Their communication is often realized via social networks where the communication is "shortened" and "abbreviated". The students would definitely need more practice in free writing.

Regarding the content of students' writing, in the argumentative essay, most of them (totally 14 students, i.e. $58 \%$ ) agreed with the claim: "Unemployment benefits could demotivate people to be active in searching for an appropriate job". They mostly expressed the opinion that in case of higher unemployment benefits, the people usually spend more time on searching for the appropriate position. Only 11 students stated also counterarguments (the others left this part out). The counterarguments brought mainly the opinion that thanks to the unemployment benefits, the people could find a job that is more convenient for them and bring them more satisfying position. One student stated that unemployment benefits are not high enough and that is why the people are motivated to find a new job in a short time. The rest of students (10 students, i.e. $42 \%)$ did not agree with the claim. Six students expressed their opinion that most of people are not satisfied with the status "to be unemployed" and are motivated to search quickly for a new job. Only three students gave also counterarguments that the process of searching for a new job could be prolonged by the unemployment benefits. Four students wrote that unemployment benefits are not high enough and people are motivated to search for a new job. One student wrote the counterargument that the situation could be different for older people because their benefit period is longer and they could be motivated to spend more time on searching for a new job. 
The method of free writing did not bring so clear results. The students came up with their ideas that were stated often similarly like in "the stream of consciousness". It is caused by relatively free structure of the free writing. To sum it up, only 6 students expressed relatively clear agreement with the claim "Unemployment benefits could demotivate people to be active in searching for an appropriate job". Two of them imagined themselves to be unemployed and they claimed that in this case, they would like to enjoy their free time and travel instead of searching for a new job. Four students did not agree with the claim. They relatively clearly expressed similar idea that people are used to have a certain "status" and to be unemployed is not representative for them. They also argued that it is not possible to survive with the unemployment benefits because the costs of living are very high (especially in Prague). One student argued that he would never register at the employment office because he perceives this place very negatively. The rest of students expressed their ideas that were not very consistent. However, the results of free writing method were surprisingly considerable.

Both methods brought interesting results and most of students perceived these activities positively. Some of them were a little lost in free writing but more practice would be certainly helpful for them.

\section{Conclusion}

The paper discussed possibilities of students' argumentative skills development in the process of teaching and was aimed at the development of students' ability to give the arguments in economic subject with the help of active teaching methods. Two selected group methods argumentative essay and free writing - in connection with practicing of argumentative abilities were presented from the theoretical point of view with focus on their organizational differences. After this section, the results of proving these methods in the teaching process were presented and discussed.

To conclude, the results of $t$-test showed the importance of differences between pre-test and post-test in both groups - both methods have significant impact on students' knowledge change. The research question was answered: There is a significant influence of argumentative methods (argumentative essay, free writing) on students' knowledge of a selected economic topic.

It could be recommended to use both methods while teaching economic subjects. But it is necessary to choose the topic well because the methods are applicable for the topics that are not too abstract for students and in which some controversial question could be discussed. It is possible to suggest e.g. the topic of "Production Possibility Frontier" or "Consumer Utility" or "Competition" (unlike the topic of "Inflation" or "Gross Domestic Product" that is more abstract for students). The detailed suggestion of convenient topics application is the aim of a future research.

The teacher should definitely know that active teaching methods are relatively timeconsuming and challenging both for students and them. In agreement with some authors [9] it is necessary to claim that classic frontal teaching has its noticeable importance (e.g. while teaching the topics with more abstraction). However, the application of these methods can be very helpful for students' future possibilities on the labor market. In the process of students' ideas presentation, the argumentative skills are developed because the students must stand up for their solutions. Undoubtedly, this ability will be assessed in their future profession.

\section{Acknowledgements}

The paper is processed with the support of the research project of the Faculty of Finance and Accounting, University of Economics, Prague, that is realized within the institutional support 
of science VŠE IP100040, with the help of "Rada Grantové agentury Akademické aliance Faktor financí a podnikavosti z hlediska rozvoje lidského kapitálu”, reg. n. GA/2018/7, and "Interní grantová agentura VŠE v Praze - Komplexní výzkum osobnosti učitele ekonomických předmětů na středních školách v ČR”, reg. n. IGS VŠE 7/2018.

\section{Literature}

[1] PLAMÍNEK, J.: Komunikace a prezentace. Grada Publishing, Prague, 2012. ISBN 97880-247-4484-1.

[2] CRYSTAL, D.: How Language Works. Penguin Books, London, 2006. ISBN 978-0141-01552-1.

[3] KOŠŤÁLOVÁ, H., et al.: Vybrané kapitoly pro rozvoj pedagogických dovedností. Oeconomica, Prague, 2010. ISBN 978-80-245-1653-0.

[4] TUTORING AND LEARNING CENTER: Argumentative Essays. [online]. 2014. [accessed 2017-01-22]. Available from WW: https://www.georgebrown.ca/uploadedFiles/TLC/_documents/Argumentative\%20Essay $\underline{\text { s.pdf }}$

[5] NAROPA WRITING CENTER: Brainstorming and Free Writing. [online]. 2014. [accessed 2017-01-20]. Available from http://naropa.edu/documents/programs/jks/naropa-writing-center/brainstorming-andfreewriting.pdf

[6] SIMKINS, S.; ALLEN, S.: Pretesting Students to Improve Teaching and Learning. International Advances in Economic Research. 2000, Vol. 6, Issue 1, pp. 100-112. Online ISSN 1573-966X. DOI: 10.1007/BF02295755

[7] UNIVERSITY OF WASHINGTON: Guidelines for pre- and post-testing: A technical implementation guide. [online]. 2008. [accessed 2017-01-20]. Available from WWW: https://assessmentinaction.files.wordpress.com/2012/08/guidelines.pdf

[8] CONTCHART: Goodness-of-fit tests for the normal distribution. [online]. 2014. [accessed 2017-01-19]. Available from WWW: http://contchart.com/goodness-offit.aspx

[9] PECINA, P.; ZORMANOVÁ, L.: Metody a formy aktivní práce žáků v teorii a praxi. Masaryk University, Brno, 2009. ISBN 978-80-210-4834-8.

Ing. Lenka Holečková, Ph.D. 


\section{PŘíNOS PSANÍ PRO ROZVOJ ARGUMENTAČNÍCH DOVEDNOSTÍ STUDENTU゚}

Článek se zabývá př́nosem písemného zachycení myšlenek studentů pro formování jejich argumentačních dovedností. Zaměřuje se na dvě písemné formy procvičování těchto dovedností - metodu volného psaní a argumentační esej - zahrnuté do vyučovacího procesu. Důraz je kladen na možnou změnu znalostí studenti̊ v rámci výuky zvoleného ekonomického tématu, a to právě za pomoci volného psaní či argumentační eseje. Tyto dvě metody se liší ve své struktuře - zatímco argumentační esej má pevně stanovené náležitosti, metoda volného psaní dovoluje studentům zapisovat související myšlenky skutečně volně bez povinných náležitostí a struktury. Obě metody jsou časově náročné a jsou určitou výzvou jak pro učitele, tak i pro studenty. Článek se zabývá možností využití těchto písemných metod ve vyučovacím procesu na př́kladu vybraného ekonomického tématu. Hlavním cílem článku je poukázat na př́nos těchto dvou metod se zaměřením na změnu znalostí studentů. V této souvislosti byl proveden experiment, jehož průběh a výsledky jsou v článku představeny a diskutovány.

\section{DER BEITRAG DES SCHREIBENS IN DER ENTWICKLUNG DER ARGUMENTATIVEN FÄHIGKEITEN DER STUDENTEN}

Diese Abhandlung beschäftigt sich mit dem Beitrag schriftlich formulierter Ideen der Schüler zur Gestaltung ihrer argumentativen Fähigkeiten im Lehrprozess. Sie konzentriert sich auf zwei Formen der Schreibfertigkeitspraxis, freies Schreiben und argumentativer Essay, die in den Lehrprozess einbezogen werden. Der Schwerpunkt liegt auf der möglichen Änderung des Wissens der Studierenden in Bezug auf ausgewählte wirtschaftliche Themen, die mittels der Methode des freien Schreibens oder der argumentativen Essay-Methode vermittelt werden. Diese beiden Methoden sind unterschiedlich: Während der argumentative Aufsatz seine strengen Teile hat, erlaubt das freie Schreiben den Studenten, freier, $d . h$ ohne eine obligatorische Struktur zu schreiben. Beide Methoden sind relativ zeitaufwendig und stellen sowohl für die Schüler als auch für den Lehrer eine Herausforderung dar. Dieser Artikel beschäftigt sich mit der Möglichkeit, diese Schreibweisen in der Lehre ausgewählter Wirtschaftsthemen zu nutzen. Das Hauptziel des Beitrags besteht darin, die Bedeutung dieser beiden ausgewählten Methoden zu zeigen, während sie sich auf ihren möglichen Einfluss auf das Wissen der Schüler konzentrieren. In diesem Zusammenhang wurde ein Experiment durchgeführt, dessen Ergebnisse am Ende des Beitrags diskutiert werden.

\section{WPŁYW PISANIA NA ROZWÓJ UMIEJĘTNOŚCI ARGUMENTACYJNYCH STUDENTÓW}

Niniejszy artykuł poświęcony jest korzyściom wynikającym z uchwycenia na piśmie pomysłów studentów dla kształtowania ich zdolności argumentacyjnych. Skupia się na dwóch formach trenowania tych umiejętności - metoda swobodnego pisania i esej argumentacyjny które są włączone w proces nauczania. Nacisk położono na możliwe zmiany w wiedzy studentów w ramach nauczania wybranego zagadnienia ekonomicznego, przy zastosowaniu metody swobodnego pisania lub eseju argumentacyjnego. Te dwie metody różnią się swoją strukturą - esej argumentacyjny ma swoje ściśle określone elementy, natomiast swobodne pisanie pozwala studentom na bardziej luźne zapisywanie ich myśli, bez konieczności przestrzegania obowiązkowych form i struktury. Obie metody są czasochłonne i są swego rodzaju wyzwaniem zarówno dla nauczycieli, jak i studentów. Artykuł poświęcony jest też możliwościom wykorzystania tych metod $\mathrm{w}$ procesie dydaktycznym na przykładzie wybranego tematu ekonomicznego. Głównym celem artykułu jest pokazanie korzyści, jakie dają te dwie metody, przy uwzględnieniu zmiany zachodzącej w poziomie wiedzy studentów. $\mathrm{W}$ tym kontekście przeprowadzono eksperyment, którego przebieg i wyniki w artykule przedstawiono i omówiono. 